\title{
The effect of ageing and lifestyle profile changes on personalization and customer relationship management (CRM)
}

\author{
Herman B. Prinsloo \\ Xansa Reading Office \\ Reading, Berkshire RG6 1PU \\ United Kingdom \\ herman.prinsloo@xansa.com
}

\section{Contents}

1. Introduction

2. How the problem started

3. Customer relationship management (CRM) definition

4. Current success of CRM and personalization

5. Problem: pushing a time bomb

6. Behavioural model of CRM: looking backward, not forward

7. Lifetime value

8. Lifecycle stages

9. Changing expectations

10. Conclusion

11. References

\section{Introduction}

One of the basics of personalization or customer relationship management (CRM) on the Internet includes leverageing data (assuming the data are accurate and aligned) that are gathered to trigger business rules. These business rules will drive information to the user, facilitating a closer relationship with the user and prompting the user to react more in a way the organization would like him or her to react (i.e. generate more revenue and remain loyal).

\section{How the problem started}

Personalization in the virtual world signifies the exact opposite of personalization in the physical world. Personalization and CRM in the virtual world strive to remove people entirely from on-line communications and aim to use business rules and algorithms that categorize, entice and up-sell customers in the name of e-commerce (Davies 2000:1). 
Personalization, as defined by Peppers, Rogers and Dorf (1999), is aimed at an interactive, real-time virtual medium such as the Internet: 'By tailoring their messages to satisfy individual needs, marketers build sustained, intimate relationships with their customers.' Snowballing profits inevitably follow from an enriched, personalized buying experience.

\section{Customer relationship management (CRM) definition}

The basics of CRM are not as new or as novel an idea as is generally accepted. In 1954, Drucker (1954) wrote: 'The true business of every company is to make and keep customers.' Today it is widely acknowledged that the way in which a company treats its customers inevitably determines its future profitability. This is why companies are making bigger investments into CRM and personalization. Customers have become more fastidious about the service they expect and are 'voting with their wallets' based on the experiences they had with companies.

Thompson (2001:1) defines CRM as a business strategy to select and manage the most valuable customer relationships. CRM requires a customer-centric business philosophy and culture to support effective marketing, sales and service processes. CRM applications can enable effective customer relationship management, provided that employees have the right leadership, strategy and culture. Novo (2000:1) focuses his definition on two areas, namely reduction in operating costs (or increased efficiency) and increased spending of the customer base.

Tamminga and O'Halloran (2000:2) define CRM more holistically as 'integrating IT solutions into a broader [business] strategy for building intimate and enduring customer relationships that drive company prosperity' and argue that a customer-driven CRM framework will typically focus on five key areas, namely:

- Customer insight- knowing customers better than they know themselves;

- customer offers- giving customers what they want rather than what you want to give them;

- customer interactions- personalizing each customer experience;

- high-performance organization-carrying out the CRM effort with the most talented staff possible; and

- enterprise integration- integrating CRM with the other systems throughout the organization.

In partial agreement with Tamminga and O'Halloran, Tiwana (2000:3) mentions two integral aspects of CRM, namely knowledge of the customer and relationship capital or digital capital. Digital capital can be compared to Tamminga and O'Halloran's customer insight. If exploited successfully, it can help create customer lock-in. Customer lock-in occurs when 'the financial and non-financial costs of switching to another business are high enough to dissuade [the customer] from switching'. Tiwana (2000:3) identifies customer loyalty as one of the strongest forms of lock-in. Companies create customer loyalty through a combination of knowledge, anticipation of future customer requirements and superior communication.

From the above, it is clear that the essence of CRM, notwithstanding the plethora of definitions available, is still about making and keeping customers (Drucker 1954) to make money.

Thompson (2001:2) identifies four business processes that are directly involved in the CRM lifecycle: 
- Marketing: targeting prospects, acquiring new customers, for example through data mining, campaign management and lead distribution

- Sales: closing business with effective selling processes using inter alia proposal generators, configurators, knowledge management tools, contact managers, forecasting aids

- E-commerce: all customers should have one touch point with the company, no matter which touch point they choose

- Service: handling post-sales service and support issues through all customer touch points, including call centre applications of Web-based customer service.

Many companies look at CRM as a panacea for an outdated customer service strategy or ailing IT infrastructure. Unfortunately, the deployment and operation of CRM without an understanding of which information is crucial lead to customer disappointment, devaluation of the brand and installation failure (Saldibar 2000:1). This is why nearly 70\% of CRM projects 'fail to deliver measurable business value' (Berg 2001:1).

From the above definitions of CRM, it is clear that CRM is more than just technology. It is a customer-centric business strategy enabled by various CRM technologies to ensure a more satisfactory customer experience to achieve the competitive advantage required for greater profitability (Anon. 2000:1). Retaining customer relationships is a top priority of CRM, as competition is often only a mouse-click away and companies can no longer compete solely on the basis of price, geography or a special distribution arrangement (Anon. 2000:2). There are currently more than 2000 vendors in 50 subsegments of the CRM market and, according to Nelson (2001:2), the average enterprise in the US has 10 to 12 vendors in place that all claim to be in the CRM market.

Despite all the attention that the CRM market has received in recent years, Gammon (2000:2) estimates that it is less than 5\% saturated. Berg (2001:1) forecasts no slowdown in corporate investment in CRM and predicts that the market for CRM products and services will be in the range of US\$5 billion to US\$ 12 billion by 2004 .

\section{Current success of CRM and personalization}

In terms of the success of personalization and CRM, it is clear that there are very few happy, fulfilled customers, record turnovers and profits. Davies (2000:2) suggests that, thus far, most attempts at CRM have been obnoxious, ineffective, overpriced or unacceptably intrusive. This is not a result of the intent of companies, but must be ascribed to the current limitations of CRM software to recognize and respond to the intricate nuances that form part of human communication. One example of CRM software is collaborative filtering software packages that work reasonably well in companies with limited product categories (e.g. books or CDs). However, the software can make ridiculous suggestions to users with odd tastes or, for example, to someone who bought a gift for a friend and now find this preference added to his/her profile. Take for example a female buying a book on carpentry for her father. She might return to the Internet bookstore and find several special, but irrelevant offers and products on carpentry displayed on the front page. However most software vendors of this kind are currently refining their software, and the problem illustrated by the example above should be eradicated within a few years as software evolves. 
The problem with many CRM activities (especially permission e-mail marketing) is that they use so-called 'push' methods to communicate to customers (e.g. 'pushing' out a monthly email to communicate product updates, special offers, event reminders, service reminders and company updates) (Van Gaalen 2001:23).

Personalized 'push' methods are generally employed to increase the likelihood of sales through targeted promotions to finally have greater profits. For 'push' technology to be successful, it generally requires a high measure of channel integration to obtain a unified view of the customer. In 1999, a survey conducted by Massachusetts-based Forrester Research found that $92 \%$ of respondents thought that a unified view of the individual customer was critical (or very important) to their company. Only $2 \%$ said that they had achieved that single, unified face to the customer and another $10 \%$ reported achieving partial integration.

Irrespective of the channel, companies are looking for answers to the same basic questions when they use analytical CRM tools. These questions can be broadly summarized as follows:

- Associations - What do people buy together? If you know which combinations of products and services your customers tend to purchase together (e.g. annuities with mutual funds or fine cheese with quality wine), you can create more efficient marketing campaigns and increase your ROI through cross-selling and up-selling.

- Segmentation and profiling - What attributes do people share? What do customers who desert your company for the competition have in common? Do you know which customer characteristics are most relevant to your profitability? Once you have identified groups of customers with similar characteristics, you can conduct special sales promotions and targeted mailings that take into account the particular needs of each group.

- Behavioural - What do people do and how do they react? What do your customers do when their bank account balances increase? What do they do when they miss three loan repayments or when they move into a new house? With the ability to anticipate likely behaviours in certain circumstances, an organization can confidently determine how best to respond.

- Exceptions - Who does not fit the norm? Data mining techniques can alert an organization to sudden drops in service usage, suspicious credit card purchases and various other divergences from usual customer behaviour. The ability to quickly identify such anomalies gives an organization the chance to take appropriate action before the window of opportunity closes.

The problem with targeted personalized push technology is that the profiles employed by the technology are generally based only on the historical data of a customer. The efficacy of CRM interactions based on historical data often shows a rapid decline over time, as illustrated by Figure 1.

Figure 1 Effect and affect of personalized profile-based e-mail marketing 


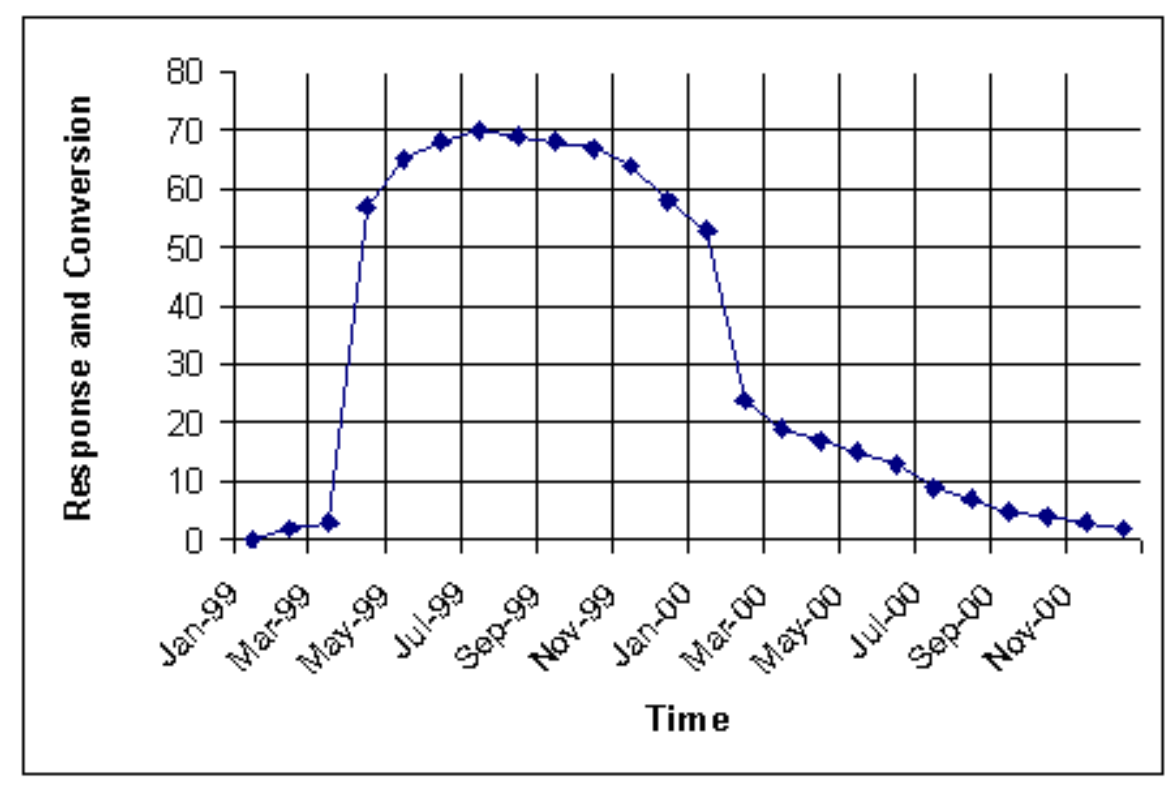

Figure 1 illustrates an actual case where a youth-oriented product was marketed to affluent teenagers via e-mail. The rapid uptake and response were followed by a fast decline in response and conversion can be clearly seen. During the entire period, the type of communication and the value of the products on offer stayed reasonably constant.

The reason why this problem exists is partly a result of the paradigm within which CRM developed. This paradigm can be referred to as the behavioural model of CRM. In other words, CRM is applied to individual customers and is based on historical behavioural data of the individual customer's interaction with the company.

This notion (or paradigm) contains one fundamental flaw that in future will become a huge problem for CRM practitioners and companies involved in CRM. The flaw is not of a technological nature, but a psychological issue and refers to the fact that a customer ages and changes with time.

Needs, interests, tastes, expectations and preferences change during an individual's lifetime and these changes can become a time bomb because database profiles of individual customers rarely get updated. The following scenario illustrates the point: A 19-year-old student joins a retail Internet banking facility. According to the database and the information gathered, the student is single, has no children and practically no assets.

After a period of five years, the student has changed from a banking perspective. The client is now 24-years-old and is a qualified chartered accountant who earns a reasonable income. The client is still single with no children and little assets. According to lifestyle profile data, the client (if he is male) will make the following major acquisitions over the medium-term: a home entertainment system, a new car and a first home.

If the bank kept track of this client's changing behaviour, it would have known that according to the demographics and lifestyle profile special short-term loans for DVDs and sound systems would have interested the client. In about a year's time, the client will be ready to buy his first car and then the bank should be prompting him about good car finance options. In four year's time, he would be ready to purchase his first home and the bank should start prompting the client with information about home loan options, as well as general information related to buying a home.

In another scenario, a 19-year-old female student joins a community portal and indicates in 
her registration form that she is interested in travel (backpacking), fashion and house music. After five years, she is a young lawyer, single, no children and has little assets. After another five years she is 29 years old, married, has no children and works in middle management in the legal department of a large investment bank. After 10 years, will the CRM system used by the community portal still forward her information about the interests that she indicated as a 19-year-old? In all probability, the individual's preferences would have changed to travel (hotel accommodation), stress management, cooking (minimum effort for maximum effect) and jazz music.

What strategies will the portal follow to ensure that it keeps in touch with her changing needs and interests?

\section{Behavioural model of CRM: looking backward, not forward}

Why is the ageing and changing of individuals such as big potential problem? In the business world, a huge profit can be generated over the lifetime of a certain individual, should offers stay relevant and just in time to the individual's current and changing needs and interests.

In banking, especially, an individual can stay with the same bank for 30 years and rarely get proactive information from the bank on the next big lifestyle event (e.g. buying a first home). Generally this results in the bank not getting the first car finance deal or the first home loan application - despite the fact that it supposedly has a lifelong relationship with the client.

\section{Lifetime value}

Novo (2000:3) defines lifetime value (LTV) as the expected net profit a customer will contribute to a business as long as the customer remains a loyal.

Figure 2 clearly illustrates that losing a customer because the messages communicated to him or her via CRM became less and less relevant can lead to the loss of revenue over the lifetime of a customer. For this reason, it is imperative that companies anticipate future individual customer needs, respond to enquiries thoroughly and within context, and learn from every customer interaction.

\section{Figure 2 Customer lifetime value}




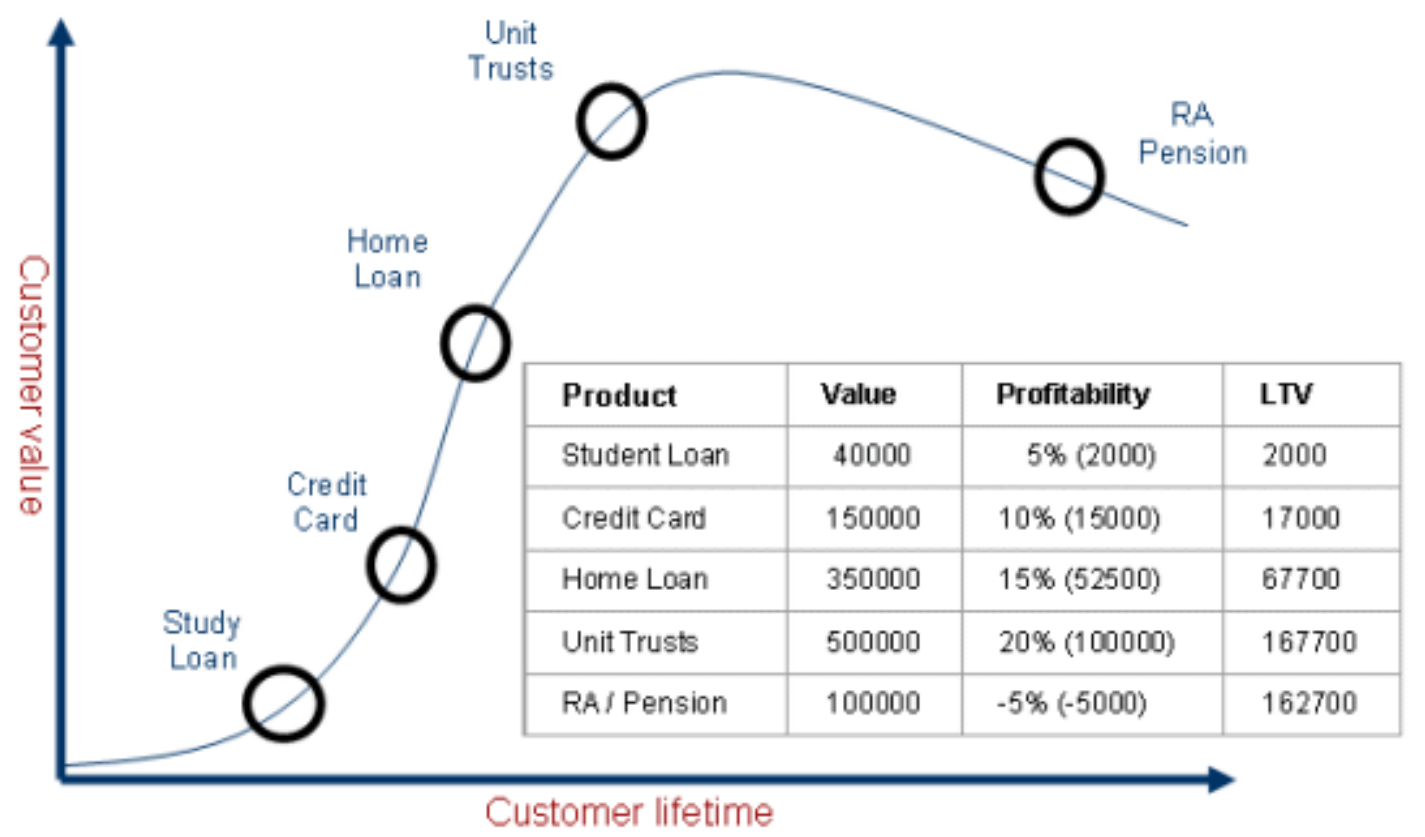

top

\section{Lifecycle stages}

Lifestyle profiling is a contentious subject at the moment. Many feel that lifestyle profiling is part of the mass marketing paradigm and that it has lost its relevance due to all the nonstandard modern lifestyle configurations that are more prevalent in the last decades (e.g. same sex unions, single parents, the briefcase family, divorcees, second and third families, people having children later in life and couples having children and not marrying). In recent years, some publications have profiled non-standard lifecycles (Siegel and Lowe 1994; Slater 1995 and Marshak, Seligman and Prezant 1999). Roozen (1996:12) successfully employs lifecycle stages as a model to explain and predict the religious activity of several American generations spanning over a period of 60 years.

In an empirical cross-cultural study conducted in the USA and New Zealand, Watson (1999:6) conclusively and that a lifecycle stage was superior to materialism in terms of its predictive and explanatory power when examining the variation in important possessions identified by subjects.

Traditionally, family lifecycle models have been used in marketing as one of the demographic factors employed to target and market products with relevance to individuals in a specific lifecycle. However, Conrad and Johnson (2000:13) warn that consumer behaviour models, which have been in use for decades to predict consumer responses to marketing stimuli (of which lifecycle models are one), may not apply in its entirety to an on-line setting. They also state that future research is necessary to validate these models for new applications, for example CMR.

Table 1 illustrates a traditional family lifecycle in the retailing market according to Kuppuswamy, Maini and Agrawat (2000:14).

Table 1 Traditional family lifecycle in the retailing market

\begin{tabular}{|l|l|l|}
\hline Stage in cycle & Characteristics & Relevance of retailing \\
\hline & &
\end{tabular}




\begin{tabular}{|c|c|c|}
\hline Bachelor & $\begin{array}{l}\text { Independent, young, } \\
\text { early stage of career and } \\
\text { earnings. }\end{array}$ & $\begin{array}{l}\text { Clothing, car, travel, café, } \\
\text { entertainment, objects for } \\
\text { the mating game. }\end{array}$ \\
\hline Newly married & $\begin{array}{l}\text { Two incomes, relative } \\
\text { independence, present } \\
\text { and future oriented. }\end{array}$ & $\begin{array}{l}\text { Furnishing apartment, } \\
\text { travel, clothing, durables, } \\
\text { appeal to togetherness. }\end{array}$ \\
\hline Full nest 1 & $\begin{array}{l}\text { Youngest child under six } \\
\text { years. One or one-and-a- } \\
\text { half income. Limited } \\
\text { independence. Future } \\
\text { oriented. }\end{array}$ & $\begin{array}{l}\text { Goods and services geared } \\
\text { towards child, family- } \\
\text { oriented items, practicality } \\
\text { of items and appeal to } \\
\text { economy. }\end{array}$ \\
\hline Full nest 2 & $\begin{array}{l}\text { Youngest child under } 6 \\
\text { years. One-and-a-half to } \\
\text { two incomes. Dependent. } \\
\text { Future oriented. }\end{array}$ & $\begin{array}{l}\text { Savings, home, education, } \\
\text { children-oriented items, } \\
\text { family vacations. Appeal } \\
\text { to comfort and luxuries. }\end{array}$ \\
\hline Full nest 3 & $\begin{array}{l}\text { Youngest child at home } \\
\text { but independent. High- } \\
\text { income level, } \\
\text { independent, thoughts of } \\
\text { retirement. }\end{array}$ & $\begin{array}{l}\text { Education, expensive } \\
\text { durables for children, } \\
\text { replacement and } \\
\text { improvement of parents' } \\
\text { durables. Appeal to } \\
\text { comfort and luxuries. }\end{array}$ \\
\hline Empty nest 1 & $\begin{array}{l}\text { No children at home, } \\
\text { independent, good } \\
\text { income, thoughts of } \\
\text { retirement and self. }\end{array}$ & $\begin{array}{l}\text { Retirement home, travel, } \\
\text { entertainment, luxuries. } \\
\text { Appeal to self- } \\
\text { gratification. }\end{array}$ \\
\hline Empty nest 2 & $\begin{array}{l}\text { Retirement, limited } \\
\text { income, present oriented. }\end{array}$ & $\begin{array}{l}\text { Travel, recreation, health- } \\
\text { related items. Little } \\
\text { interest in luxury. Appeal } \\
\text { to comfort. }\end{array}$ \\
\hline Sole survivor 1 & $\begin{array}{l}\text { Only one spouse alive, } \\
\text { good income, employed, } \\
\text { present oriented. }\end{array}$ & $\begin{array}{l}\text { Immersion in jobs and } \\
\text { friends, travel, } \\
\text { entertainment, clothing } \\
\text { and health. }\end{array}$ \\
\hline Sole survivor 2 & $\begin{array}{l}\text { Only one spouse alive, } \\
\text { limited income, retired. }\end{array}$ & $\begin{array}{l}\text { Travel, entertainment, } \\
\text { health-related items. } \\
\text { Appeal to economy and } \\
\text { social activity. }\end{array}$ \\
\hline
\end{tabular}

In addition to the lifecycle changes, Kuppuswamy et al. (2000:15) also identify the following lifestyle trends that affect the modern consumer:

- Gender roles: an increasing number of working women alter family lifestyles significantly. Forrester Research predicts that half of all US women will be on-line by 2003 (Strauss and Frost 1999:55).

- Consumer sophistication and confidence: an increasing number of consumers have cosmopolitan tastes and styles and are more knowledgeable and demanding than before. Expected outcomes of this include a) a decreased desire for conformity; b) more willingness to experiment; c) insistence on detailed information; and d) a stronger demand for quality goods and services. 
- Poverty of time: as a result of a) more working women; b) increases in distances between locations of work and home; and c) more people working second jobs. Poverty of time affects consumer shopping patterns and buying behaviour.

\section{Changing expectations}

Just as changes in an individual's lifecycle happen largely unnoticed, organizations often do not note the gradual, but significant changes in consumers' expectations.

Table 2 illustrates how consumer expectations of a car (as a marketing object) changed between 1970 and 1990.

Table 2 Consumer expectations of a car (as a marketing object) between 1970 and 1990

\begin{tabular}{|l|l|l|l|}
\hline & Ca. 1970 & Ca. $\mathbf{1 9 8 0}$ & Ca. 1990 \\
\hline Generic & $\begin{array}{l}\text { Chassis, full-size } \\
\text { spare wheel, } \\
\text { engine }\end{array}$ & $\begin{array}{l}\text { Leatherette seats, } \\
\text { four gears }\end{array}$ & $\begin{array}{l}\text { Cloth seats, five } \\
\text { gears, small spare } \\
\text { wheel }\end{array}$ \\
\hline Expected & $\begin{array}{l}\text { Rear view mirror, } \\
\text { leatherette seats, } \\
\text { three gears, split } \\
\text { front seats }\end{array}$ & $\begin{array}{l}\text { Front safety belts, } \\
\text { one side mirror, } \\
\text { fuel economy }\end{array}$ & $\begin{array}{l}\text { Safety belts front } \\
\text { and back, two side } \\
\text { mirrors, } \\
\text { immobilizer }\end{array}$ \\
\hline Augmented & $\begin{array}{l}\text { Four gears, one } \\
\text { side mirror, front } \\
\text { safety belts }\end{array}$ & $\begin{array}{l}\text { Cloth seats, two } \\
\text { side mirrors, five } \\
\text { gears }\end{array}$ & $\begin{array}{l}\text { Six gears, factory } \\
\text { fitted radio, ABS, } \\
\text { leather seats }\end{array}$ \\
\hline Potential & $\begin{array}{l}\text { Two side mirrors, } \\
\text { electric windows, } \\
\text { central locking, } \\
\text { fuel economy }\end{array}$ & $\begin{array}{l}\text { Back safety belts, } \\
\text { electric windows, } \\
\text { ABS, electrically } \\
\text { adjustable seats }\end{array}$ & $\begin{array}{l}\text { Full-size spare } \\
\text { wheel, satellite } \\
\text { tracking, bumper } \\
\text { sensors and } \\
\text { tiptronic gears }\end{array}$ \\
\hline
\end{tabular}

From Table 2, it is clear that consumer expectations of any product can change rapidly over time. Fuel economy, for example, was not a great issue in 1970, but became a deciding factor by 1980. Expectations can also have fluctuating importance. In 1970, people did not value a full-size spare wheel much, but by 1990 a full-size spare wheel became an important consideration when people bought a car.

Very few CRM implementations consider that customers tend to get 'used to' or 'familiar' with any given product or offering and do not have strategies in place to upgrade their offering to match the rising expectations of their consumers. This factor places a long-term customer base at risk as competitors can easily augment their offerings and 'rob' customers.

\section{top}

\section{Conclusion}

One of the aims of CRM is to build long-term relationships with customers to gain the most possible profit from a customer over the duration of his or her lifetime (also referred to as maximising the LVT of the customer). Building long-term relationships implies that: 
- a company must continue to innovate and grow its product or service to continually match up to customers' ever-increasing expectations - companies must prevent brands from growing stale or old fashioned;

- a company's relationship with the time-deprived customer must continue to stay relevant in the eyes of the customer - the brand must keep up to date with who the customer is; and

- a company must be ahead of the competition in terms of the actual or perceived value of an offer presented to an individual client. This is to make it difficult (if not impossible) for the customer to contemplate shifting from a company to its competition. The company must evaluate how its brand competes in terms of price, service, value, integrity, quality, etc. in the mind of the individual customer.

The current behavioural model of CMR as discussed in this article highlights the need for a CRM model that is forward-looking. CMR technology and profiling must be improved to take into account historical behaviour-based data as well as possible lifecycle changes in an individual's lifetime. Furthermore, anticipated future behaviour or needs, as well as changes in user expectations must be accommodated or satisfied.

'If customers are in fact the drivers of the new economy, then CRM applications rest squarely in the oncoming headlights. The train can't be stopped, and no one can get out of the way fast enough to keep from getting blown away. CRM is the bomb on the train, and it is headed your way' (Highsmith, 2000:1).

\section{References}

Anon. 2000. The CRM Phenomenon White Paper. [Online].

Available WWW: http://www.magic-sw.com.

Anon. 2001. The customer relationship management primer: what you need to know to get started. 3rd ed. [Online].

Available at: http://www.crmguru.com/content/papers/crm_primer.html.

Berg, H. 2001. Avoiding the stresses after CRM installations. [Online].

Available WWW: http:/www.computerworld.com/cwi/story/0,1199,NAV47-68-861721STO56245,00.html.

Conrad, C.A. and Johnston, T. 2000. Search engines in the e-promotions mix: a preliminary empirical investigation. [Online].

Available WWW: http://www.utm.edu/ johnston/epromotions.htm.

Davies, P. 2000. The trouble with (im)personalization. [Online].

Available WWW: http://www.computeruser.com/articles/1911,6,30,1,1101,00.html.

Drucker, P.F. 1954. The practice of management. New York: Harper and Row.

Gammon, R. 2000. Why do CRM installations fail? [Online]. Available WWW: http://www.businesssolutionsmag.com/Articles/2000_09/000916.htm. 
Highsmith, J. 2000. CRM: implementing customer-centric strategies. [Online].

Available WWW: http://cutter.com/itgroup/reports/crmcustomer.html.

Kuppuswamy, A., Maini, A., Agrawal, A., Meratwal, L. and Kejriwal, N. 2000. Analysis of the retailing industry. [Online].

Available WWW: http://www.projectshub.com/projects/110011/110011d.htm.

Marshak, L.E., Seligman, M. and Prezant, F. 1999. Disability and the family lifecycle. New York: Basic Books.

Nelson, S. 2001. The implications of the 2001 CRM hype cycle. Gartner Group Research Note DF-13-0755, 3 April 2001. [Online].

Available WWW: http://www.gartnergroup.com.

Novo, J. 2000. Tracking the potential profitability (ROI) of B2C CRM implementations. [Online]. Available WWW: http://crm.ittoolbox.com/browse.asp?

$\mathrm{c}=$ CRMPeerPublishingandr=\%2Fpub\%2FCRM\%2DROI\%2Ehtm.

Peppers, D., Rogers, M. and Dorf, B. 1999. The one to one field book: the complete toolkit for implementing a 1to1-marketing program. New York: Doubleday.

Roozen, D.A. 1996. Empty nest; empty pew: the boomers continue through the family cycle. [Online].

Available WWW: http://hirr.hartsem.edu/bookshelf/roozen_article1.html.

Saldibar, S. 2000. CRM: just part of the solution. [Online].

Available WWW: http://www.crmxchange.com/sessions/crm/jan01.html.

Siegel, S. and Lowe, E. 1994. Uncharted lives: understanding the life passages of gay men. New York: Dutton.

Slater, S. 1995. The lesbian family lifecycle. Champaign, IL: University of Illinois Press.

Strauss, J. and Frost, R. 1999. Marketing on the Internet: principles of online marketing. New York: Prentice Hall.

Tamminga, P. and O'Halloran, P. 2000. Finding the real value in CRM: leverageing the customer-driven approach. In Implementing customer-centric strategies. [Online].

Available WWW: http://cutter.com/itgroup/reports/crmcustomer.html).

Thompson, B. 2001. What is CRM? In The customer relationship management primer: what you need to know to get started. 3rd ed. [Online].

Available WWW: http://www.crmguru.com/content/papers/crm_primer.html).

Tiwana, A. 2000. KCRM: beyond 'word of mouse'. In Implementing Customer-Centric Strategies. [Online]. 
Available WWW: http://cutter.com/itgroup/reports/crmcustomer.html).

Van Gaalen, M. 2001. Rapid sugar e-mail marketing crash course. [Online].

Available WWW: http://www.rapidsugar.nl/crashcourse.pdf.

Watson, J.J. 1999. A cross-cultural comparison of the explanatory power of materialism and lifecycle stage for important possessions. [Online].

Available WWW: http://marketing.byu.edu/htmlpages/ccrs/proceedings99/watson.htm.

\section{Disclaimer}

Articles published in SAJIM are the opinions of the authors and do not necessarily reflect the opinion of the Editor, Board, Publisher, Webmaster or the Rand Afrikaans University. The user hereby waives any claim he/she/they may have or acquire against the publisher, its suppliers, licensees and sub licensees and indemnifies all said persons from any claims, lawsuits, proceedings, costs, special, incidental, consequential or indirect damages, including damages for loss of profits, loss of business or downtime arising out of or relating to the user's use of the Website.

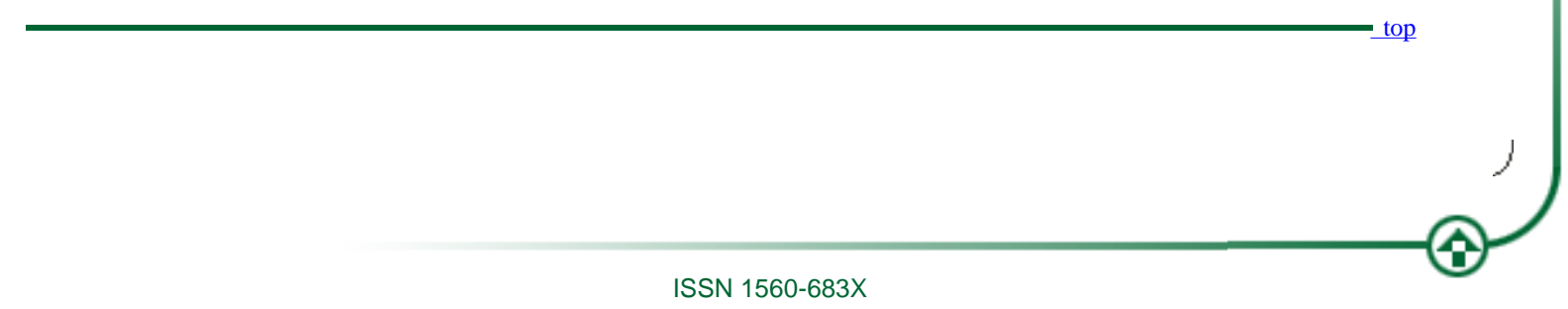

Published by InterWord Communications for the Centre for Research in Web-based Applications, Rand Afrikaans University 